\title{
Gradients in N-cycling attributes along forestry and agricultural land-use systems are indicative of soil capacity for $\mathbf{N}$ supply
}

\author{
D. S. L. Fagottit ${ }^{1}$, M. Y. H. Miyauchi ${ }^{2}$, A. G. Oliveira ${ }^{1}$, I. A. Santinoni ${ }^{1}$, D. N. Eberhardt ${ }^{2}$, A. Nimtz $^{1}$, \\ R. A. Ribeiro ${ }^{1}$, A. M. Paula ${ }^{2}$, C. A. S. Queiroz ${ }^{1}$, G. Andrade ${ }^{1}$, W. Zangaro ${ }^{1}$ \& M. A. Nogueira ${ }^{1}$ \\ ${ }^{1}$ Universidade Estadual de Londrina, C.Postal 6001, CEP 86051-990, Londrina, PR, Brazil, and ${ }^{2}$ Universidade de São Paulo, \\ C. Postal 09, CEP 13418-900, Piracicaba, SP, Brazil
}

\begin{abstract}
Indicators of soil quality associated with N-cycling were assessed under different land-use systems (native forest - NAT, reforestation with Araucaria angustifolia or Pinus taeda and agricultural use AGR) to appraise the effects on the soil potential for $\mathrm{N}$ supply. The soil total $\mathrm{N}$ ranged from 2 to $4 \mathrm{~g} / \mathrm{kg}$ (AGR and NAT, respectively), and the microbial biomass $\mathrm{N}$ ranged from 80 to $250 \mathrm{mg} / \mathrm{kg}$, being higher in NAT and $A$. angustifolia, and lower in $P$. taeda and AGR sites. Activities of asparaginase (ca. 50-200 mg NH${ }_{4}^{+}-\mathrm{N} / \mathrm{kg}$ per h), glutaminase (ca. 200-800 mg NH${ }_{4}{ }^{+}-\mathrm{N} / \mathrm{kg}$ per h) and urease (ca. 80-200 mg $\mathrm{NH}_{4}{ }^{+}-\mathrm{N} / \mathrm{kg} / \mathrm{h}$ ) were also more intense in the NAT and $A$. angustifoliareforested soils, indicating greater capacity for $\mathrm{N}$ mineralization. The NAT and AGR soils showed the highest and the lowest ammonification rate, respectively (ca. 1 and $0.4 \mathrm{mg} \mathrm{NH}_{4}{ }^{+}-\mathrm{N} / \mathrm{kg}$ per day), but the inverse for nitrification rate (ca. 12 and 26\%), indicating a low capacity for $\mathrm{N}$ supply, in addition to higher risks of $\mathrm{N}$ losses in the AGR soil. A multivariate analysis indicated more similarity between NAT and $A$. angustifolia-reforested sites, whilst the AGR soil was different and associated with a higher nitrification rate. In general, reforestation with the native species A. angustifolia had less impact than reforestation with the exogenous species $P$. taeda, considering the soil capacity for $\mathrm{N}$ supply. However, AGR use caused more changes, generally decrease in indicators of N-cycling, showing a negative soil management effect on the sustainability of this agroecosystem.
\end{abstract}

Keywords: Ammonification, Araucaria angustifolia, microbial biomass nitrogen, nitrification, Pinus taeda, soil enzymes

\section{Introduction}

Araucaria angustifolia (Bert.) O. Kuntze (Brazil Pine or Pinheiro-do-Paraná) is the only member of the Araucariaceae in Brazil and is typically found in the Mixed Ombrophylous Forest that composes the Atlantic Forest biome. Besides ecological functions, A. angustifolia is also considered one of the most important natural-occurring species owing to its economical and social roles (Auler et al., 2002). Because of intense exploitation of timber for wood and cellulose industries, and the expansion of agricultural areas on the

Correspondence: M. A. Nogueira. E-mail: nogueira@,

cnpso.embrapa.br

Present address: Embrapa Soja, C.Postal 231, 86001-970 Londrina PR Brazil.

Received July 2011; accepted after revision April 2012 native forest (NAT) for centuries, A. angustifolia has been included on the list of Brazilian plant species in need of attention (FAO, 1986). Nowadays, the forestry remnants of A. angustifolia are only about $2 \%$ of the original area (Guerra et al., 2002). The use of $A$. angustifolia in the wood industry in the past was mainly based on naturally occurring trees, without reforestation of the exploited areas, as the natural resources were still available. With the decline of wood availability, reforestation programmes based on exogenous species like Pinus sp. started (Guerra et al., 2002) and occupied areas previously covered in NAT.

Climax native vegetation in an ecosystem is considered to be self-sustainable and is generally in equilibrium. The original plant covering in an ecosystem contributes to a stable biological soil community. However, after cleaning and substitution of the vegetation, greater ranges of soil 
temperature, eolic and hydric erosion, drying and soil compaction will occur, decreasing the levels of soil organic matter, microbial activity and, consequently, affecting the dynamics of carbon and nutrients (Li et al., 2004; Smolander et al., 2006).

Nitrogen $(\mathrm{N})$ is the most limiting nutrient for plant growth under low fertility, like most part of the Brazilian soils. In addition, $\mathrm{N}$ dynamics in soil is also associated with environmental risks like water and air pollution via nitrate leaching and denitrification, respectively. The main transformations of $\mathrm{N}$ into the soil is mediated by microbial processes that result in $\mathrm{N}$ immobilization in microbial and in plant biomasses, and later in the soil organic matter (Schulten \& Schnitzer, 1998; Chen et al., 2003). The mineralization of organic $\mathrm{N}$ relies on several microbial processes and its availability to plants will also depend on processes like immobilization, mineralization and several oxi-reduction reactions that determine the $\mathrm{N}$ dynamics in the environment (Krave et al., 2002; Li et al., 2004; Smolander et al., 2006).

Different land-use systems have raised the interest in indicators of soil quality for inference on the sustainability and risks of environmental degradation. Assessment of physical, chemical, biochemical and biological soil properties contributes to the understanding of the effects of land-use on essential roles carried out in the soil, like the biogeochemical cycles (Badiane et al., 2001; Velasquez et al., 2007). The replacement of native vegetation by annual crops, or even by exogenous woody species like Pinus, may affect the original soil biological and biochemical properties, and, consequently, the biogeochemical cycles. The intensity and direction (increase or decrease in a given process) caused by changes in land-use will determine the degree of degradation of a particular system and if it can be considered sustainable or not.

Despite some attempts (Velasquez et al., 2007), there is no consensus regarding the definition of a soil quality index that could be employed to understand or predict the effects of land-use on the sustainability of native or agricultural systems. Facing this difficulty, comparison with natural areas as reference seems to be feasible (Nogueira et al., 2006) and could be a way to correlate the land-use effects with the sustainability of the system under assessment.

Soil microorganisms and enzymes are generally altered in number and activity owing to changes in the land-use system, and thus can be used as indicators of soil quality owing to their fast response to changes in the environment (Nogueira et al., 2006). Moreover, soil enzymes have the potential for use as an integrated biological assessment owing to their close relationship with soil biota and the functional roles they play (Bandick \& Dick, 1999). Substrate concentration, humidity, temperature, $\mathrm{pH}$, pollutants and vegetation type are among the factors that affect soil enzyme activities (Nayak et al., 2007). A positive correlation between amidohydrolases (Lasparaginase, L-glutaminase and urease) with organic carbon and total $\mathrm{N}$ at the topsoil has been observed, indicating an interrelationship between enzyme activities, microorganisms and soil organic matter (Deng \& Tabatabai, 1996).

Regarding the soil total $\mathrm{N}$, about $90 \%$ is in organic form and thus $\mathrm{N}$ dynamics is closely reliant on the soil biota (Schulten \& Schnitzer, 1998) and enzyme activities. Some enzymes like asparaginase and glutaminase act on $\mathrm{N}$ mineralization, whilst urease acts on urea hydrolysis, making mineral $\mathrm{N}$ available for plants and microorganisms (Deng \& Tabatabai, 1996).

The aim of this work was to assess nine indicators of soil quality related to the $\mathrm{N}$-cycling, in sites under four different land-use systems: NAT, long-term reforestation with the native species $A$. angustifolia, long-term reforestation with the exogenous species Pinus taeda and agricultural land-use with annual crops. The hypothesis was that long-term reforestation with exogenous species and agricultural use would cause deeper changes in biological and biochemical indicators of soil quality related to N-cycling and thus affecting the soil capacity for $\mathrm{N}$ supply, in contrast to sites with NAT or reforested with the native species A. angustifolia.

\section{Materials and methods}

\section{Location of sites and sampling}

Soil sampling was performed in September 2006 (austral spring) in sites under different land-uses at the Irati's National Forest, consisting of 3618.21 ha with NAT and long-term reforestations with Araucaria angustifolia or Pinus taeda, located at the Irati municipality, Paraná State, Southern Brazil $\left(25^{\circ} 24^{\prime} 34.30^{\prime \prime} \mathrm{S}, 50^{\circ} 35^{\prime} 36.40^{\prime \prime} \mathrm{W}\right)$ (Figure 1). The landscape is slightly undulated to undulated, with an average altitude of $885 \mathrm{~m}$ above sea level. The soil originated from sedimentary rocks (siltites and folheles), naturally acidic ( $\mathrm{pH} 3.4-3.8$ in the forestry, and 4.6 in the agricultural soils), dystrophic $\left(<50 \%\right.$ of the CEC occupied by $\mathrm{K}^{+}, \mathrm{Ca}^{2+}$ and

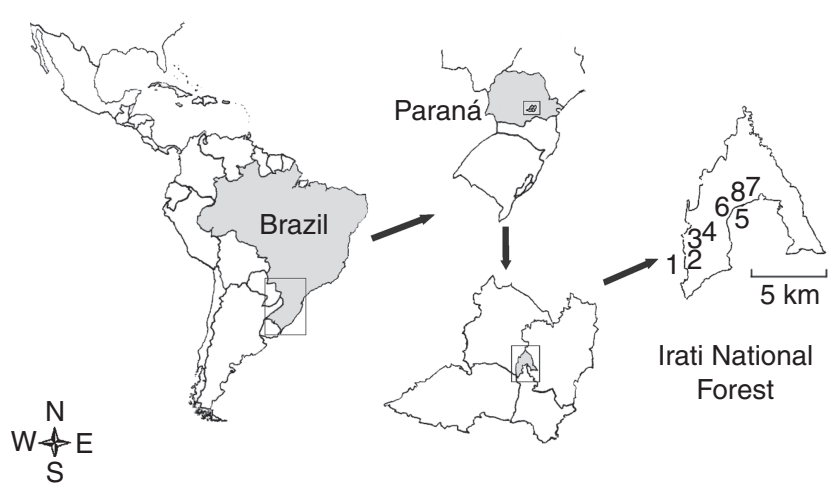

Figure 1 Location of the sampling sites: native forest (4 and 8), reforestation with Araucaria angustifolia (2 and 6), reforestation with Pinus taeda (3 and 7) and agricultural use (1 and 5). 
$\mathrm{Mg}^{2+}$ in the B horizon), deep (more than $2 \mathrm{~m}$ ), clay-loamy, with granular structure, well-drained, classified as Rhodic Ferralsol (FAO, 1998) in all land-use systems. The climate is classified as $\mathrm{Cfb}$ according to Köppen, with well-defined seasons, average rainfall between 1500 and $1600 \mathrm{~mm}$, well distributed through the year, with occurrence of temperatures below freezing point in the winter. The average annual temperature is $18^{\circ} \mathrm{C}$ ranging from -2 to $+32^{\circ} \mathrm{C}$.

We considered four contrasting land-use systems consisting of native forest (NAT) (Ombrophillic Mixed Forest seasonal semi-deciduous Atlantic forest), reforestation with Brazil pine (A. angustifolia) established in the 1940s (AR) or loblolly pine ( $P$. taeda) established in the 1950s (PI) in areas previously exploited for native tea (Ilex paraguariensis) within typical communitarian pastures for cattle based on the native vegetation, locally named 'faxinal', and wood exploitation (A. angustifolia and Imbúia - Ocotea porosa), from 1870 to 1940s, when reforestations with Pinus and annual crops started in the region. In addition, agricultural (AGR) sites with annual crops bordering the National Forest were also included. Data on botanic composition in NAT and AR sites were taken from Rode et al. (2009), only taking into account trees with trunks larger than $10 \mathrm{~cm}$ in diameter at breast height. The density in NAT sites is 506 trees/ha, with predominance of Ilex paraguariensis (55/ha), Ocotea odorifera (52/ha) and A. angustifolia (42/ha), among 108 species. In the AR sites, the density is 780 trees/ha, with a predominance of $A$. angustifolia (298/ha), followed by Myrsine umbellata (72/ha), Psychotria vellosiana (57/ha), Casearia sylvestris (45/ha), Cabralea canjerana (44/ha), among 79 species. In both conditions, there are other plant species in the understory like pteridophytes, gramineous and bushes. In the PI sites, the density of P. taeda is around 1000 plants/ha, consisting of plants about $30 \mathrm{~m}$ in height. In the west sites, the PI understory is clear, with very few occurrences of herbaceous species, whilst in the east sites, the understory is dominated by herbaceous species, including pteridophytes and gramineous. The AGR sites close to the National Forest are cropped in two cycles per year, with soybean or maize in the summer, and wheat, oat or ryegrass in the winter since the 1980s. The production system is mechanized from soil preparation to harvest. The soil is managed conventionally by ploughing or chiselling $(20 \mathrm{~cm}$ depth), followed by disc harrowing (two or three times) before sowing each crop; they receive mineral fertilizers, limestone and agrochemicals.

In each land-use system, eight composite soil samples were taken, four in the west side and four in the east side of the National Forest (Figure 1). Each composite sample comprised 15 single subsamples taken at $0-0.1 \mathrm{~m}$ depth along transect lines of $25 \times 5 \mathrm{~m}$, randomly delimited on the sites representative of each land-use system.

Field-moist samples were stored at $5{ }^{\circ} \mathrm{C}$ and used for microbial and biochemical analyses that were performed up to 1 week after sampling, whilst total $\mathrm{N}$ was determined from air-dried samples.

\section{Microbiological, chemical and biochemical analyses}

The soil total $\mathrm{N}$ was assessed by sulphuric digestion, followed by Kjeldahl distillation (Bremner \& Mulvaney, 1982). Microbial biomass nitrogen (MBN) was estimated by the fumigation extraction method (Vance et al., 1987), taking into account the increase in $\mathrm{N}$ in the fumigated aliquot in relation to the non-fumigated counterpart, and considering an extraction coefficient $\left(\mathrm{K}_{\mathrm{N}}\right)$ of 0.68 (Brookes et al., 1985).

Ammonification and nitrification rates were calculated taking into account the ammonium and nitrate concentrations in the samples (with and without $125 \mu \mathrm{g} / \mathrm{g}$ of ammoniacal-N) before and after incubation at $28{ }^{\circ} \mathrm{C}$ for 21 days in the dark (Schuster \& Schroder, 1990). Ammonium and nitrate were quantified in field-moist samples after extraction with $2 \mathrm{~m} \mathrm{KCl}$, followed by double Kjeldahl distillation and titration (Keeney \& Nelson, 1982).

Activities of asparaginase, glutaminase and urease were quantified after incubation at $37^{\circ} \mathrm{C}$ for $2 \mathrm{~h}$ in the appropriate $\mathrm{pH}$ and enzyme substrate (L-asparagine, L-glutamine and urea, respectively) (Tabatabai \& Bremner, 1972; Frankenberger \& Tabatabai, 1991). The ammonium produced by hydrolysis of the respective substrate was extracted with $\mathrm{KCl}-\mathrm{AgSO}_{4}$, Kjeldahl-distillated and titrated (Keeney \& Nelson, 1982).

\section{Statistical analyses}

The dataset was analysed by ANOVA and Tukey's test $(P \leq 0.05)$, in a randomized blocks design, that is, one block at each side of the National Forest (east and west) with four replications within each block. In addition, the dataset was submitted to a multivariate analysis using principal component analysis (PCA), to look for relationships between the land-use systems and the attributes of the N-cycling related to them, using the Canoco 4.5 for Windows ${ }^{\circledR}$ software (Braak \& Smilauer, 1998).

\section{Results}

The soil total $\mathrm{N}$ was the highest in NAT and decreased in the following order: NAT $>$ AR $>$ PI $=$ AGR (Figure 2a). Similar trend was observed for microbial biomass $\mathrm{N}$, in which the AGR site showed about one-third of the microbial biomass $\mathrm{N}$ found in NAT and AR sites (Figure 2b). Ammonium concentration was the highest in the soil of the NAT site, followed by AR and PI, and finally the AGR site with the lowest level (Figure 2c). Nitrate differed only between PI and AR sites, the highest and lowest amounts, respectively (Figure 2d). The nitrate- $\mathrm{N}$ to ammonium-N ratios were higher in P. taeda (1.6 SD 1.1) and agricultural 

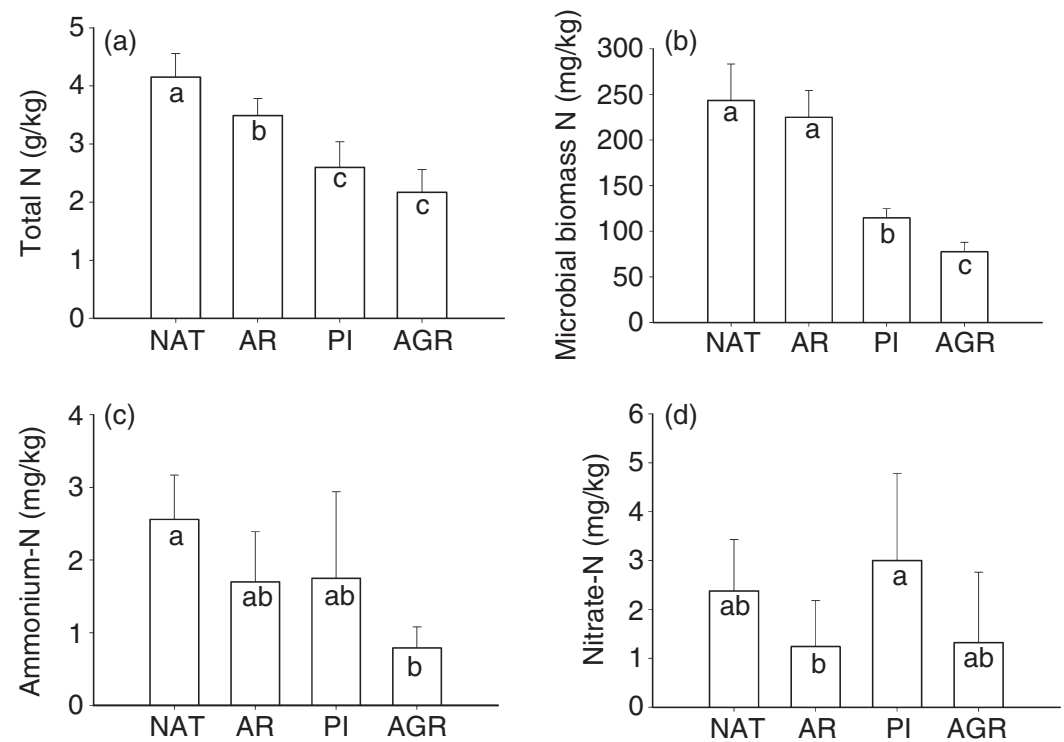

Figure 2 Different forms of $\mathrm{N}$ [Total $\mathrm{N}$ (a), Microbial Biomass N (b), Ammonium-N (c) and Nitrate-N (d)] and processes of $\mathrm{N}$ transformations [Ammonification (e) and Nitrification (f) rates] in soils under different land-use systems: native forest (NAT), reforestation with Araucaria angustifolia (AR), reforestation with Pinus taeda (PI) and agricultural (AGR). Vertical bars show the standard deviation $(n=8)$.
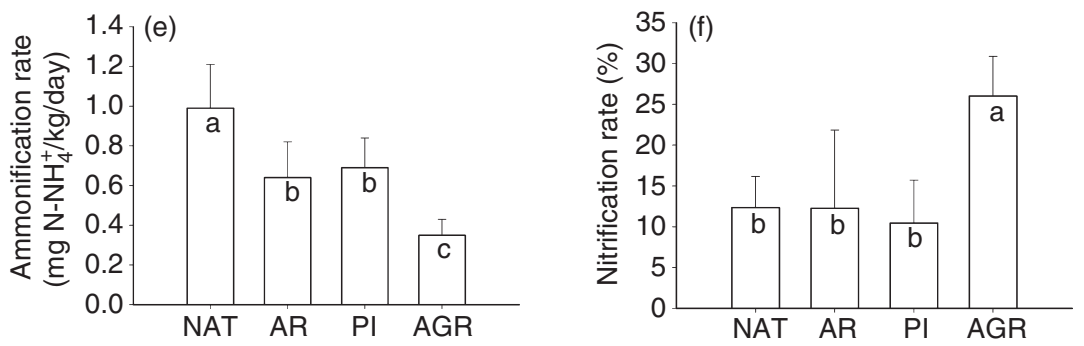

(1.7 SD 1.5) soils, as compared with the native (1.0 SD 0.4) and A. angustifolia (1.0 SD 1.1) soils. Ammonification rate was the highest in the soil of NAT site, followed by AR and PI soils, and finally the AGR soil with the lowest rate (Figure 2e). Conversely, the nitrification rate was the highest in the AGR soil, and similar among the forestry sites (Figure 2f).

The land-uses deeply changed the enzyme activities related to N-cycling (Figure 3). The highest activities occurred in the NAT and AR soils, followed by PI and AGR. The asparaginase activity was three times lower in the AGR in comparison with the AR soil. Considering only the forestry sites, PI showed about half the enzyme activity (Figure 3a). The same was observed for glutaminase, where activities in the NAT and AR soils were more than three times higher than in PI and AGR (Figure 3b). A similar trend was observed for urease activity (Figure $3 \mathrm{c}$ ).

Considering the PCA, the NAT and AR soils showed more similarity to each other, followed by PI, and finally the AGR soil, which was the most dissimilar (Figure 4). NAT and AR soils were similar in microbial biomass $\mathrm{N}$, enzyme activities, ammonification rates and total $\mathrm{N}$. Nitrification rate was associated with the AGR site, whilst all the other variables correlated negatively. Nitrate was more associated with the PI-reforested site.

\section{Discussion}

In general, concentrations of mineral $\mathrm{N}$ in mineral soils are low owing to microbial transformations that lead to losses by leaching as nitrate or by denitrification as gasses (Krave et al., 2002). Thus, the $\mathrm{N}$ in soil organic matter and microbial cells are important reservoirs (Brussaard et al., 2004) that depend on mineralization driven by soil microorganisms and their enzymatic arsenal to be made available. Many factors such as complexity of soil organic matter, quality of residues (e.g. C:N, resins), clay content, moisture, $\mathrm{pH}$ affect the organic $\mathrm{N}$ mineralization rate (Krave et al., 2002). In fact, the organic $\mathrm{N}$ in the microbial biomass is easily mineralizable owing to its low C:N ratio (5-10:1) (Chen et al., 2003). In the present work, the soil reforested with the native species Araucaria angustifolia had similar microbial biomass $\mathrm{N}$ compared with the NAT, whilst the soil reforested with Pinus taeda had 50\% less microbial biomass; and even less was observed in the agricultural soil, showing a smaller reservoir of potentially mineralizable N. Microbial biomass $\mathrm{N}$ was associated with total $\mathrm{N}$, both occurring in higher levels in the NAT and $A$. angustifolia-reforested soils. Such differences in total $\mathrm{N}$ and $\mathrm{MBN}$ can be credited to the dynamics and quality of organic residues that enters the soil in each landuse. In a similar study, in the same region, Bini (2009) found 

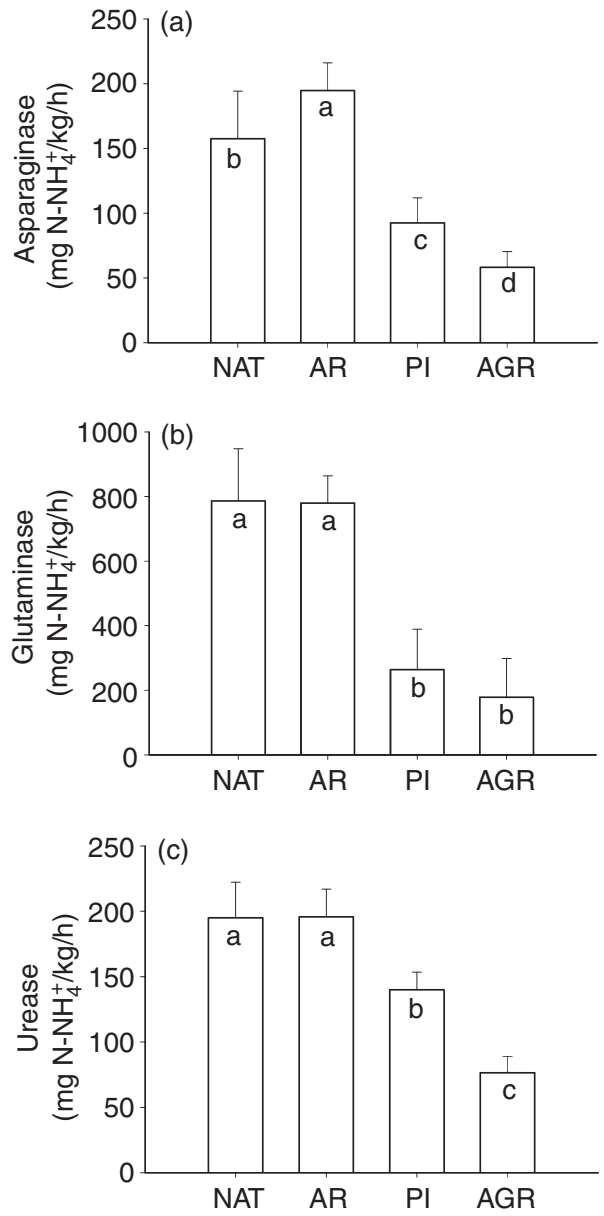

Figure 3 Activity of enzymes related to N-cycling [Asparaginase (a), Glutaminase (b) and Urease (c)] in soils under different land-use systems: native forest (NAT), reforestation with Araucaria angustifolia (AR), reforestation with Pinus taeda (PI) and agricultural (AGR). Vertical bars show the standard deviation $(n=8)$.

litter accumulation of $10.5 \mathrm{t} /$ ha for NAT, $17.2 \mathrm{t} / \mathrm{ha}$ for reforestation with $A$. angustifolia, $22.4 \mathrm{t} /$ ha for reforestation with Pinus and $3.8 \mathrm{t} / \mathrm{ha}$ in an agricultural soil use. The respective $\mathrm{C}: \mathrm{N}$ ratios were 23.1, 25.4, 43.3 and 44.1. Litter derived from $A$. angustifolia had a $\mathrm{C}: \mathrm{N}$ ratio similar to the NAT litter, whilst Pinus produces a litter poorer in N, resulting in lower stocks of total and microbial $\mathrm{N}$ in soil. In addition, the diversity of plant species in the $P$. taeda understory is restricted owing to allelopatic effects (Sartor et al., 2009), leading to a less diverse litter. Moreover, volatile organic compounds naturally occurring in Pinus, like terpenes also affect negatively the soil $\mathrm{N}$ transformations. Terpenes are defence compounds against pathogens in some conifers like Pinus, which also affect negatively the soil microbial biomass and net $\mathrm{N}$ mineralization (Smolander et al., 2006). Concerning the agricultural use, not only the quality (high $\mathrm{C}: \mathrm{N})$, but smaller inputs of mulching result in less microbial

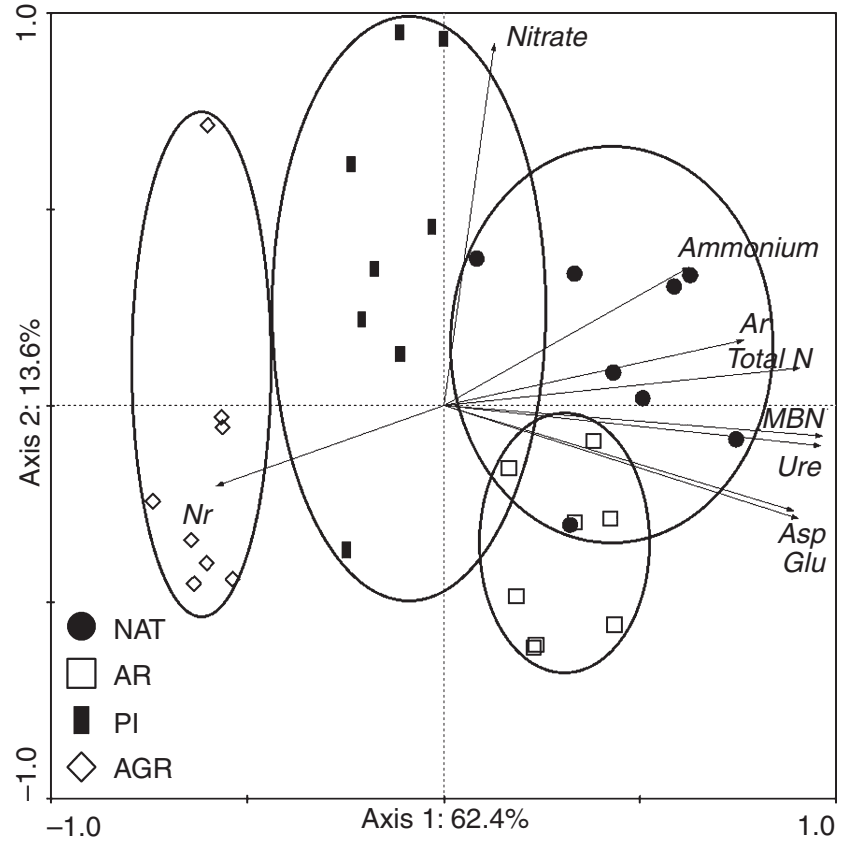

Figure 4 Factorial plan of a principal component analysis based on microbial $(M B N$, microbial biomass nitrogen; $A r$, ammonification rate; $N r$, nitrification rate), biochemical (Asp, asparaginase; Glu, glutaminase; Ure, urease) and chemical (Ammonium; Nitrate; and Total $N$ ) attributes in soils under different land-use systems: native forest (NAT), reforestation with Araucaria angustifolia (AR), reforestation with Pinus taeda (PI) and agricultural (AGR).

community inputs, notably the microbial biomass $\mathrm{N}$ ( $\mathrm{Li}$ et al., 2004). Thus, the soil use has important effects on the easily available forms of $\mathrm{N}$, and consequently on the capacity to meet the plant demands.

Removal of native vegetation or substitution may cause major modifications in the soil microbial processes associated with $\mathrm{N}$ dynamics as observed in this work and elsewhere (Li et al., 2004; Nogueira et al., 2006; Smolander et al., 2006; Davidson et al., 2007). For instance, the higher ammonification rate in the NAT soil indicates a greater potential for nitrogen release from organic stocks, followed by the reforested sites, either with A. angustifolia or with P. taeda. However, even after long-term reforestation, the potential for $\mathrm{N}$ mineralization in the reforested sites is below that observed in the NAT soil. Despite Araucaria-reforested soil has more favourable conditions for ammonification (enzyme activities, total $\mathrm{N}$ and microbial $\mathrm{N}$ ) than Pinus, ammonification rate was similar in both. A combination of the differences in the soil organic matter quality and microbial community after longterm reforestation may have changed the soil $\mathrm{N}$-cycling in both soils (Zhong \& Makeschin, 2006) leading to similar ammonification. However, the soil with Pinus has fewer total and microbial N stocks than Araucaria-reforested soil, which can be emptied earlier in case of clear cutting and conversion to agricultural use. Finally, the agricultural soil had the lowest 
potential for $\mathrm{N}$ supply, which makes that system more dependent on external inputs for plant maintenance. In addition, the agricultural soil showed the highest nitrification rate, a process predominantly carried out by autotrophic microorganisms (Schulten \& Schnitzer, 1998). This is negative, because nitrate- $\mathrm{N}$ is easily lost by leaching and denitrification, mainly between the crop cycles, or after fertilizer applications, when mineral $\mathrm{N}$ availability in soil is greater than plant uptake capacity. Thus, the soils under forestry land-uses are more capable of supplying the nitrogen requirements to plants, by having more total and microbial $\mathrm{N}$, higher ammonification rates and lower nitrification rates, whereas the agricultural soil depends on external input owing to lower capacity to supply $\mathrm{N}$, and greater vulnerability to nitrogen losses as consequence of faster nitrification rates.

Extractable ammonium increased from agricultural to NAT soils, indicating increasing availability of soil $\mathrm{N}$ in the forestry sites, as expected. Taking into account the total N, $\mathrm{MBN}$, ammonification rates and enzyme activities, the pools of organic $\mathrm{N}$ are being concomitantly mineralized by microbial and biochemical processes in soil. Ammonium- $\mathrm{N}$ is generally the prevailing inorganic $\mathrm{N}$ in $\mathrm{N}$-limited soils, whereas nitrate- $\mathrm{N}$ prevails under more abundance of $\mathrm{N}$ (Davidson et al., 2007). Nevertheless, our results showed predominance of nitrate- $\mathrm{N}$ over ammonium- $\mathrm{N}$ in $P$. taeda and agricultural soils, which showed lower potential for $\mathrm{N}$ supply compared with the native and $A$. angustifoliareforested soils. Although plants and microorganisms immobilize ammonium-N after ammonification, chemoautotrophic bacteria oxidizes it to nitrate (Krave et al., 2002). Thus, not only the prevalence of mineral $\mathrm{N}$ but also total and microbial $\mathrm{N}$, ammonification and nitrification rates, and N-cycling enzyme activities should be considered to infer the soil capacity for $\mathrm{N}$ supply. According to the multivariate analysis, except for nitrate and nitrification rate, the $\mathrm{N}$-cycling-related attributes correlated with one another and were high in the NAT and $A$. angustifolia-reforested sites. The higher nitrification rate associated with the agricultural soil can be attributed to less microbial biomass and less vegetation density, and consequently less competition for ammonium, in addition to higher $\mathrm{pH}$ (4.6), which are favourable to nitrification.

The N-cycling-related enzymes (asparaginase, glutaminase and urease) act on the mineralization of organic $\mathrm{N}$ and are involved in the $\mathrm{N}$-cycling in soil. Higher activities were observed in the NAT and A. angustifolia-reforested soils, but decreased in $P$. taeda and agricultural soils. Not only the land-use system, but also the qualities of residues that return to the soil affect the enzyme activities (Nayak et al., 2007). In this case, the activities in the soil reforested with A. angustifolia for more than $60 \mathrm{yr}$ were similar to the NAT soil, despite the higher density of $A$. angustifolia trees in the reforested sites. Residues from $P$. taeda have typically higher $\mathrm{C}: \mathrm{N}$ ratio, in addition to resins containing terpenes that impair the $\mathrm{N}$ mineralization, microbial activity and biomass, and as a consequence, reduce the N-cycling-related enzyme activities (Smolander et al., 2006). Thus, this could explain the different results for $\mathrm{N}$-cycling attributes in $P$. taeda as compared with $A$. angustifolia-reforested soils. In contrast to $P$. taeda, the low enzyme activity in the agricultural soil is attributable to fewer inputs of organic residues (Bini, 2009), resulting in less microbial biomass as well as substrate for enzyme activities.

A diverse vegetal covering stimulates the soil enzyme activities owing to a more diverse input of organic residues, increasing the stocks of soil organic $\mathrm{N}$ and the soil microbial community, which is the main source of soil enzymes (Nayak et al., 2007). In general, land-use systems that stimulate soil microbial communities also stimulate the soil enzyme activities. The more constant entrance of organic residues into the forestry soils (native or reforested) stimulates the soil microbial activity specialized in using such residues as substrate, resulting in a larger pool of extracellular enzymes. On the other hand, negative effects on the soil microbial activity are also negative to the soil enzymes. Accordingly, the enzyme activities increased in soils that were left under long-term natural regeneration and with greater vegetal diversity (Badiane et al., 2001). In addition, enzymes like L-asparaginase, L-glutaminase and urease are positively correlated with the soil organic matter (Deng \& Tabatabai, 1996). Nevertheless, it must be noted that reforestation with the exogenous species $P$. taeda increased asparaginase and urease activities in relation to the agricultural soil, but less than in the A. angustifolia-reforested soil, in comparison with the reference NAT soil.

\section{Conclusions}

In summary, reforestation with the native species A. angustifolia maintains the soil properties associated with $\mathrm{N}$-cycling to levels very near to the NAT, whilst the exotic species $P$. taeda causes changes in the indicators of soil Ncycling towards the agricultural soil use. This aspect should be considered in future reforestation programmes aiming at preservation of biodiversity, given that the soil processes supporting the forest nutrition are more promptly re-established when using native species, and thus increasing the sustainability of the reforested site. The agricultural soil use was shown to be the most dissimilar and strongly associated with higher nitrification rates, suggesting that such conventional land-use system is not sustainable considering the soil capacity for $\mathrm{N}$ supply.

\section{Acknowledgements}

We thank CNPq, CAPES and Fundação Araucária for graduate fellowships. M. A. Nogueira and G. Andrade are CNPq scholars. This paper was approved for publication by 
the Editorial Board of Embrapa Soja as manuscript number $13 / 2011$.

\section{References}

Auler, N.M.F., Reis, M., Guerra, M.P. \& Nodari, R.O. 2002. The genetics and conservation of Araucaria angustifolia: I. Genetic structure and diversity of natural populations by means of nonadaptive variation in the state of Santa Catarina, Brazil. General Molecular Biology, 25, 329-338.

Badiane, N.N.Y., Chotte, J.L., Pate, E., Masse, D. \& Rouland, C. 2001. Use of soil enzyme activities to monitor soil quality in natural and improved fallows in semi-arid tropical regions. Applied Soil Ecology, 18, 229-238.

Bandick, A.K. \& Dick, R.P. 1999. Field management effects on soil enzyme activities. Soil Biology and Biochemistry, 31, 1471-1479.

Bini, D. 2009. Bioindicadores de qualidade de solo em diferentes ecossistemas (Bioindicators of soil quality in different ecosystems) (Master Scientiae dissertation). Available at: http://www.biblioteca digital.uel.br/document/?code $=$ vtls000147957; accessed 12/04/ 2012.

Braak, C.J.F. \& Smilauer, P. 1998. CANOCO Reference Manual and User's Guide to Canoco for Windows: Software for Canonical Community Ordination (version 4). Microcomputer Power, Ithaca, NY, USA.

Bremner, J.M. \& Mulvaney, C.S. 1982. Nitrogen-total. In: Methods of soil analysis, part 2: chemical and microbiological properties (eds A.L. Page, R.H. Miller \& D.R. Keeney), pp. 595-624. American Society of Agronomy, Madison.

Brookes, P.C., Landman, A., Pruden, G. \& Jenkinson, D.S. 1985. Chloroform fumigation and the release of soil nitrogen: A rapid direct extraction method to measure microbial biomass nitrogen in soil. Soil Biology and Biochemistry, 17, 837-842.

Brussaard, L., Kuyper, T.W., Didden, W.A.M., De Goede, R.G.M. \& Bloem, J. 2004. Biological soil quality: From biomass to biodiversity - importance and resilience to management stress and disturbance. In: Managing Soil Quality: challenges in Modern Agriculture (eds P. Schjonning, S. Elmholt \& B.T. Christensen), pp. 139-161. CAB International, Wallingford, UK.

Chen, G., Zhu, H. \& Zang, Y. 2003. Soil microbial activities and carbon and nitrogen fixation. Research in Microbiology, 154, 393-398.

Davidson, E.A., Carvalho, C.J.R., Figueira, A.M., Ishida, F.Y., Ometto, J.P.H.B., Nardoto, G.B., Saba, R.T., Hayashi, S.N., Leal, E.C., Vieira, I.C.G. \& Martinelli, L.A. 2007. Recuperation of nitrogen cycling in Amazonian forests following agricultural abandonment. Nature, 447, 995-998.

Deng, S.P. \& Tabatabai, M.A. 1996. Effect of tillage and residue management on enzyme activities in soils: I. Amidohydrolases. Biology and Fertility of Soils, 22, 202-207.

FAO. 1986. Databook on endangered tree and shrub species and provenances. FAO Forestry Paper No. 77. Food and Agriculture Organization of the United Nations, Rome, Italy.

FAO. 1998. World reference base for soil resources. World Soil Resources Reports, No. 84. Food and Agriculture Organization of the United Nations, Rome, Italy.

Frankenberger, W.T. \& Tabatabai, M.A. 1991. Asparaginase activity of soils. Biology and Fertility of Soils, 11, 6-12.
Guerra, M.P., Silveira, V., Reis, M.S. \& Schneider, L. 2002. Exploração, manejo e conservação da araucária (Araucaria angustifolia). In: Sustentável Mata Atlântica (eds L.L. Simões \& C.F. Lino), pp. 85-101. SENAC, São Paulo.

Keeney, D.R. \& Nelson, D.W. 1982. Nitrogen inorganic forms. In: Methods of soil analysis, part 2: Chemical and microbiological properties (eds A.L. Page, R.H. Miller \& D.R. Keeney), pp. 643698. American Society of Agronomy, Madison.

Krave, A.S., van Straalen, N.M. \& van Verseveld, H.W. 2002. Potential nitrification and factors influencing nitrification in pine forest and agricultural soils in Central Java, Indonesia. Pedobiologia, 46, 573-594.

Li, Q., Allen, H.L. \& Wollum, A.G. 2004. Microbial biomass and bacterial functional diversity in forest soils: effects of organic matter removal, compaction, and vegetation control. Soil Biology and Biochemistry, 36, 571-579.

Nayak, D.R., Babu, Y.J. \& Adhya, T.K. 2007. Long-term application of compost influences microbial biomass and enzyme activities in a tropical Aeric Endoaquept planted to rice under flooded condition. Soil Biology and Biochemistry, 39, 1897-1906.

Nogueira, M.A., Albino, U.B., Brandão-Júdior, O., Braun, G., Cruz, M.F., Dias, B.A., Duarte, R.T.D., Gioppo, N.M.R., Menna, P., Orlandi, J.M., Raiman, M., Rampazo, L.G.L., Santos, M.A., Silva, M.E.Z., Vieira, F.P., Torezan, J.M.D., Hungria, M. \& Andrade, G. 2006. Promising indicators for assessment of agroecosystems alteration among natural, reforested and agricultural land use in southern Brazil. Agriculture, Ecosystems and Environment, 115, 237-247.

Rode, R., Figueiredo-Filho, A., Galvão, F. \& Machado, S.A. 2009. Comparação florística entre uma Floresta Ombrófila Mista e uma vegetação arbórea estabelecida sob um povoamento de Araucaria angustifolia de 60 anos. Cerne, 15, 101-115.

Sartor, L.R., Adami, P.F., Chini, N., Martin, T.N., Marchese, J.A. \& Soares, A.B. 2009. Alelopatia de acículas de Pinus taeda na germinação e no desenvolvimento de plântulas de Avena strigosa. Ciência Rural, 39, 1653-1659.

Schulten, H.R. \& Schnitzer, M. 1998. The chemistry of soil organic nitrogen: a review. Biology and Fertility of Soils, 26, 1-15.

Schuster, E. \& Schroder, D. 1990. Side effects of sequentially-applied pesticides on target soil microorganisms: field experiments. Soil Biology and Biochemistry, 22, 67-373.

Smolander, A., Ketolab, R.A., Kotiaho, T., Kanerva, S., Suominen, K. \& Kitunen, V. 2006. Volatile monoterpenes in soil atmosphere under birch and conifers: Effects on soil N transformations. Soil Biology and Biochemistry, 38, 3436-3442.

Tabatabai, M.A. \& Bremner, J.M. 1972. Assay of urease activity in soil. Soil Biology and Biochemistry, 4, 479-487.

Vance, E.D., Brookes, P.C. \& Jenkinson, D.S. 1987. An extraction method for measuring soil microbial biomass C. Soil Biology and Biochemistry, 19, 703-707.

Velasquez, E., Lavelle, P. \& Andrade, M. 2007. GISQ, a multifunctional indicator of soil quality. Soil Biology and Biochemistry, 39, 3066-3080.

Zhong, Z. \& Makeschin, F. 2006. Differences of soil microbial biomass and nitrogen transformation under two forest types in central Germany. Plant and Soil, 283, 287-297. 